\title{
E-GOVERNANCE ADOPTION IN GOVERNMENT ORGANIZATION OF INDIA
}

\author{
Mithun Barua \\ L.M Thapar School of Management, Thapar University, India \\ mbdels@gmail. com
}

\begin{abstract}
India, the growing economic super-power proceeded with lightning speed towards the adoption and successful implementation of e-governance. The Government of West Bengal (federal unit of India) implemented e-governance in pension office i.e. Pension Management System (PMS), for faster and efficient delivery of public services. The success of PMS is dependent on many factors and one among them is the successful adoption by the employee which has been empirically analyzed. The study used the Technology Acceptance Model (TAM) and Trust to build a conceptual model. Data collected from 60 employees working on the system and the model is assessed with regression analyses. The findings show that the determinants of the research model are support. The study also shows that the system doesn't perform completely error free tasks which the Government of West Bengal should address. This is the first study of employee adoption of e-governance in pension office of India.
\end{abstract}

\section{KEY WORDS}

e- Governance Adoption, UTAUT, Trust, Pension Management System (PMS), DPPG

\subsection{Introduction}

The Directorate of Pension, Provident Fund and Group Insurance (DPPG), Government of West Bengal, India came into being in the year 1983. It is under the administrative control of the Finance Department, Government of West Bengal, India. Initially, this Directorate used to deal with municipal pension cases only. Later on, with the passage of time, the pension cases of teachers of primary and non-government educational institutions, panchayat (local government) and municipal employees, employees of Khadi Board, Higher Secondary Education Council, West Bengal Pollution Control Board, College Service Commission, Social Welfare Board etc have come under the aegis of the Directorate. The Directorate is headed by a Director and the total staff strength is 115 as on $31^{\text {st }}$ March 2012.

e- Governance initiatives in the Directorate started in 1990 with computerization of its operations and automation. The Directorate first issued computer generated Pension Payment Order (PPO) in 1990. The program of 'DPPG Computerization Project' was started in 1994 and the National Informatics Centre (NIC) was entrusted for its implementation. With the advancement of technology, NIC implemented the 'Pension Management System (PMS)'. The entire process of the pension calculation, processing, generation and reports are carried out with the help of PMS. As on $31^{\text {st }}$ March 2012, there are 60 employees of the Directorate working on the system and more than 0.3 million pension orders have been successfully processed and generated. 
The e-governance initiatives in the Directorate and its field establishments have technologically matured in phases but the acceptance and adoption of these e-governance initiatives (the Pension Management System) by the facilitator (Officers/ staff) has never been considered. In the presented work, an attempt has been made to empirically study the factors impacting the acceptance and adoption of Pension Management System (PMS), which is the government-togovernment (G2G) application system in the Directorate of Pension, Provident Fund and Group Insurance (DPPG) of the Government of West Bengal (federal unit of India) by the officers and subordinate staffs.

\subsection{Literature Review}

There is no clear definition of what is adoption in the e-governance adoption studies (Foteinou 2011). Two of the most influential authors in e-governance adoption, Carter and Belanger (2005) associate adoption with the intention to use, while Warkentin et al. (2002) consider acceptance as the initial intention of the purpose of use (Foteinou, 2011). Gilbert and Balestrini (2004), measure it as intention to engage to e-government. Literature in the field has mentioned different reasons for the adoption of e-government (AlAwadhi and Morris, 2008): political, economic, social and managerial reasons.

Korpelainen (2011) did a detailed citation analysis of 330 articles published in leading management and business journals during 1999- 2010 and found that Technology Acceptance Model (TAM) (Davis, 1989), Theory of Reasoned Action (TRA) (Fishbein and Ajzen, 1975), Diffusion of Innovation (DOI) (Rogers', 1983), Theory of Planned Behavior (TPB) (Ajzen, 1991), Unified Theory of Acceptance and Use of Technology (UTAUT), Model of the IT Implementation Process (Cooper and Zmud, 1990), and Information Systems Success Model (DeLone and Mclean, 1992) are the most widely used and empirically tested adoption and acceptance models, used in the information systems research. In the e-governance adoption and acceptance research, the models are mainly based on the popular technology adoption models of IS research such as Technology Acceptance Model (TAM), TAM 2, Diffusion of Innovations (DOI), Theory of Planned Behavior (TPB), Unified Theory of Acceptance and Use of Technology (UTAUT), Theory of Reasoned Action (TRA) and Trust. Rana et al, (2011) on the basis of the analysis of 70 articles found that the TAM, TAM 2, DOI, UTAUT, TPB and Trust are the most widely used models in the e-governance acceptance and adoption.

\subsection{Unified Theory of Acceptance and Use of Technology (UTAUT)}

Venkatesh et al. (2003) reviewed the user acceptance literature and made empirical analysis of eight most significant models - Theory of Reasoned Action (TRA), Technology Acceptance Model (TAM), Motivational Model, Theory of Planned Behavior (TPB), a model combining TAM and TPB, Model of PC Utilization, Innovation Diffusion Theory and the Social Cognitive Theory. Than proposed the Unified Theory of Acceptance and Use of Technology (UTAUT). Venkatesh et al (2003) postulated two direct determinants of usage behavior, 'intention to use' and 'facilitating conditions'. Intention to use is influenced by performance expectancy, effort expectancy and social influence. Gender, age, experience and voluntariness of use act as moderators.

Performance expectancy is defined as the degree to which an individual believes that use of the system will help improve his/her job performance (Venkatesh et al., 2003). Effort expectancy is the degree of ease associated with the use of the system (Venkatesh et al., 2003). This construct 
parallels with the perceived ease of use of TAM (Davis, 1989; Davis et al., 1992) and ease of use in IDT (Rogers, 1995). Social influence is the degree to which an individual perceives that important others believe she/he would use the new system and it will enhance pride and esteem. Facilitating conditions refer to the degree to which an individual believe that an organizational and technical infrastructure exists to support use of the system (Venkatesh et al., 2003).

The UTUAT model has been widely used in the study of adoption of e-governance in different countries of the world. An insight into the established studies shows that the model has been empirically tested for the study of e-governance adoption in the domains of Government-toCitizens (G2C) and Government-to-Business (G2B) mainly. There are very few studies in the government-to-government (G2G) adoption and acceptance of e-governance. Gupta et al. (2008) applied this model in their study of e-governance adoption in a government organization under the Ministry of Environment \& Forests, Government of India. The study showed that all the constructs - performance expectancy, effort expectancy, social influence and facilitating conditions have positive impact on the behavior intention of the government employees towards the use of the e-governance application system. But they don't find any effect of the moderating factors. Keramati and Chelbi (2011) conducted a study related to the adoption of e-government services by government employees of Rasht municipality in Iran, particularly those working online payment of tax of renovation. The UTUAT model was used as the conceptualized model and the results identified the factors which influence e-government adoption by employees.

\subsection{Trust}

Trust appeared once with the humanity and the development of social interaction. Almost every aspect of a person life is based in one or another way in trust. So, trust is a very rich concept, covering a wide range of relationships, conjoining a variety of objects. The concept of trust is intimately linked to risk and expectations: trust is used as a substitute for risk, but it also creates a risk for the truster (Bouckaert and Van de Walle, 2001).

Trust is the most common construct that is integrated into the e-government adoption models. Trust eases the transactions in uncertain situations by reducing the perceived complexity of the situation (Pavlou, P. A. 2003). According to Colesca (2009), "Trust in e-government is an abstract concept that underlies a complex array of relationships, so the method used to quantify trust in e-government should therefore account for this abstract nature."

The most cited empirical studies in the above mentioned categories of e-governance adoption models are presented in Table 1.

Table 1: Most Cited Empirical Studies

\begin{tabular}{|c|c|c|c|}
\hline $\begin{array}{l}\text { SR } \\
\text { No. }\end{array}$ & $\begin{array}{l}\text { Adoption } \\
\text { Models }\end{array}$ & $\begin{array}{l}\text { e-Governance studies based on this } \\
\text { framework }\end{array}$ & Variables \\
\hline 1. & $\begin{array}{l}\text { Unified } \\
\text { Theory of } \\
\text { Acceptance } \\
\text { and Use of } \\
\text { Technology } \\
\text { (UTUAT) }\end{array}$ & $\begin{array}{l}\text { Al Gahtani et al. (2007), Al-Shafi \& } \\
\text { Weerakkody (2009), Dawood Sallem } \\
\text { Hussain (2009), Shafi Homoud Al- Shafi } \\
\text { (2009), Chan et al. (2010), Vencatachellum } \\
\text { \& Pudaruth (2010), Abdulwahab \& Dahalin } \\
\text { (2011), Keramati \& Chelbi (2011), Lessa et } \\
\text { al. (2011), Alzahrani \& Goodwin (2012) }\end{array}$ & $\begin{array}{l}\text { Performance expectancy, } \\
\text { effort expectancy, social } \\
\text { influence, } \\
\text { conditions. }\end{array}$ \\
\hline
\end{tabular}


International Journal of Managing Public Sector Information and Communication Technologies (IJMPICT) Vol. 3, No. 1, September 2012

\begin{tabular}{|l|l|l|l|l|}
\hline 2. & Trust literature & $\begin{array}{l}\text { Carter \& Belanger (2005), Belanger \& } \\
\text { Carter (2008), Reddick (2005), West } \\
(2004), \text { Riedl (2004), Warkentin et al. } \\
(2002)\end{array}$ & $\begin{array}{l}\text { Trust of the actor providing } \\
\text { the service, General } \\
\text { Predisposition to trust, Social } \\
\text { Demographics (gender, } \\
\text { education etc.), Party } \\
\text { Affiliation, Cultural factors, } \\
\text { Risk perceptions. }\end{array}$ \\
\hline
\end{tabular}

\subsection{Government- to- Government (G2G)}

According to Realini (2004), government-to-government (G2G) e-governance is an area which is at the nascent stage of research. As per Realini (2004), there is haziness about the domain area of $\mathrm{G} 2 \mathrm{G}$ e-governance acceptance and adoption thereby resulting in lack of commonly accepted definition. One of the widely accepted definitions of G2G e-governance can be considered as the implementation of IT solutions between and inside public administration. According to Realini (2004) E- government is the leverage from a pure bureaucratic and stovepipe organization to a pure process- oriented and seamless Government. Intra and intergovernmental E- Government have to be much more than simply wires and computers. G2G Electronic Government can be viewed as a coalition of many different aspects: from strategy to organization or from security to change in culture. G2G has the different tasks of completely redesigning the way government works and the way employees cooperate and performs.

Most of the literature and the publications on e-governance are focused on the spectacular (from the citizen's point of view) front office interactions between Government and citizens or business (i.e. G2C or G2B) (Realini, 2004). Table 2 provides a snapshot view of the studies conducted on the employee adoption of the e-governance application(s).

Table 2: G2G e-governance adoption studies

\begin{tabular}{|c|c|c|c|c|c|}
\hline $\begin{array}{l}\text { SL } \\
\text { No. }\end{array}$ & $\begin{array}{c}\text { Author \& } \\
\text { Year }\end{array}$ & Country & Respondents & Variables & Results/ Outcomes \\
\hline 1. & $\begin{array}{l}\text { Vathanopha } \\
\text { s et al. } \\
\text { ( 2006) }\end{array}$ & Thailand & $\begin{array}{l}\text { Naval Officers in the } \\
\text { Naval Finance } \\
\text { Deaprtment }\end{array}$ & $\begin{array}{l}\text { Technology } \\
\text { Acceptance } \\
\text { Model } \\
\text { ( Perceived } \\
\text { Usefulness \& } \\
\text { Perceived Ease } \\
\text { of Use) }\end{array}$ & $\begin{array}{l}\text { Found that external } \\
\text { factors affecting } \\
\text { perception of officers }\end{array}$ \\
\hline 2. & $\begin{array}{l}\text { Reddick et } \\
\text { al. } \\
(2007)\end{array}$ & $\begin{array}{c}\text { Texas \& } \\
\text { Florida, } \\
\text { USA }\end{array}$ & City Managers & $\begin{array}{l}\text { Questionnaire } \\
\text { analysis }\end{array}$ & $\begin{array}{lr}\text { e- } & \text { Government } \\
\text { having } & \text { positive } \\
\text { impact. } & \end{array}$ \\
\hline 3. & $\begin{array}{l}\text { Sahu \& } \\
\text { Gupta } \\
\text { ( 2007) }\end{array}$ & India & $\begin{array}{l}\text { Employees of Indian } \\
\text { Central Excise } \\
\text { Department }\end{array}$ & $\begin{array}{l}\text { Technology } \\
\text { Acceptance } \\
\text { Model } \\
\text { ( Perceived } \\
\text { Usefulness \& } \\
\text { Perceived Ease } \\
\text { of Use) }\end{array}$ & $\begin{array}{l}\text { Calculated the total } \\
\text { effect of each } \\
\text { variable on the } \\
\text { intention to use e- } \\
\text { government. }\end{array}$ \\
\hline 4. & $\begin{array}{l}\text { Gupta et al } \\
.(2008)\end{array}$ & India & $\begin{array}{l}\text { Employee of an } \\
\text { office under Ministry } \\
\text { of Environment \& }\end{array}$ & $\begin{array}{l}\text { Unified Theory } \\
\text { of Acceptance } \\
\text { and Use of }\end{array}$ & $\begin{array}{lr}\text { Performance } \& \text { effort } \\
\text { expectancy, } & \text { social } \\
\text { influences } & \text { and }\end{array}$ \\
\hline
\end{tabular}


International Journal of Managing Public Sector Information and Communication Technologies (IJMPICT) Vol. 3, No. 1, September 2012

\begin{tabular}{|c|c|c|c|c|c|}
\hline & & & Forests, India & $\begin{array}{l}\text { Technology } \\
\text { (UTAUT). }\end{array}$ & $\begin{array}{l}\text { facilitating conditions } \\
\text { positively impact the } \\
\text { use of ICT. }\end{array}$ \\
\hline 5. & $\begin{array}{l}\text { Hung et al. } \\
\text { ( 2008) }\end{array}$ & Taiwan & $\begin{array}{l}\text { Employees of } \\
\text { National Tax } \\
\text { Administration }\end{array}$ & $\begin{array}{l}\text { Theory of } \\
\text { Planned } \\
\text { Behavior }\end{array}$ & $\begin{array}{l}\text { Results strongly } \\
\text { support the utilization } \\
\text { of TPB in predicting } \\
\text { user's intention. }\end{array}$ \\
\hline 6. & $\begin{array}{l}\text { Sang et al. } \\
\text { ( 2009) }\end{array}$ & $\begin{array}{c}\text { Cambodi } \\
\mathrm{a}\end{array}$ & $\begin{array}{l}\text { Public Information } \\
\text { Officers in } 12 \\
\text { Ministries }\end{array}$ & $\begin{array}{l}\text { TAM, TAM2, } \\
\text { DOI and Trust }\end{array}$ & $\begin{array}{l}\begin{array}{l}\text { Determinants of the } \\
\text { research } \\
\text { supported. }\end{array} \\
\end{array}$ \\
\hline 7. & $\begin{array}{l}\text { Previtali et } \\
\text { al. } \\
(2009)\end{array}$ & Italy & $\begin{array}{l}\text { Employees of } 49 \\
\text { small municipalities }\end{array}$ & $\begin{array}{l}\text { Questionnaire } \\
\text { Analysis }\end{array}$ & $\begin{array}{l}\text { Successful in finding } \\
\text { the reasons and } \\
\text { barriers of employee } \\
\text { adoption. }\end{array}$ \\
\hline 8. & $\begin{array}{l}\text { Luarn at al. } \\
(2009)\end{array}$ & Taipei & $\begin{array}{l}\text { Employees of Taipei } \\
\text { City Government }\end{array}$ & $\begin{array}{l}\text { Task- to- } \\
\text { Performance } \\
\text { Chain Model }\end{array}$ & $\begin{array}{l}\text { Three factors that } \\
\text { affect performance: } \\
\text { task- technology fit, } \\
\text { computer self- } \\
\text { efficacy and } \\
\text { utilization. }\end{array}$ \\
\hline 9. & $\begin{array}{l}\text { Sang } \\
(2010)\end{array}$ & $\begin{array}{c}\text { Cambodi } \\
\text { a }\end{array}$ & $\begin{array}{l}\text { Information Officers } \\
\text { in Thai Ministries }\end{array}$ & TAM and Trust & $\begin{array}{l}\text { Factors influencing } \\
\text { end-user adoption of } \\
\text { the GAIS are } \\
\text { significantly affected } \\
\text { by perceived } \\
\text { usefulness, relative } \\
\text { advantage and trust. }\end{array}$ \\
\hline 10. & $\begin{array}{l}\text { Padhi et al. } \\
\text { ( 2010) }\end{array}$ & $\begin{array}{l}\text { Odisha, } \\
\text { India }\end{array}$ & $\begin{array}{l}\text { Employees of } \\
\text { different government } \\
\text { departments }\end{array}$ & $\begin{array}{l}\text { Technology } \\
\text { Acceptance } \\
\text { Model }\end{array}$ & $\begin{array}{l}\text { Successful in finding } \\
\text { the status of the } \\
\text { adoption and the } \\
\text { barriers. }\end{array}$ \\
\hline 11. & $\begin{array}{l}\text { Alhussain } \\
\text { \& Drew } \\
\text { ( 2010) }\end{array}$ & $\begin{array}{l}\text { Saudi } \\
\text { Arabia }\end{array}$ & $\begin{array}{l}\text { Employees of } \\
\text { Government } \\
\text { Departments }\end{array}$ & $\begin{array}{l}\text { Survey and } \\
\text { Questionnaire } \\
\text { Analysis }\end{array}$ & $\begin{array}{l}\text { Found out significant } \\
\text { digital and cultural } \\
\text { gap. }\end{array}$ \\
\hline 12. & $\begin{array}{l}\text { Al- Busaidy } \\
\text { et al.( 2011) }\end{array}$ & Oman & $\begin{array}{l}\text { Employees of three } \\
\text { public service } \\
\text { agencies }\end{array}$ & $\begin{array}{l}\text { Questionnaire } \\
\text { Analysis }\end{array}$ & $\begin{array}{l}\text { Measured the } \\
\text { successful adoption } \\
\text { and acceptance. }\end{array}$ \\
\hline 13. & $\begin{array}{l}\text { Singh et al. } \\
(2011)\end{array}$ & $\begin{array}{l}\text { Uttarakha } \\
\text { nd, Indi }\end{array}$ & $\begin{array}{l}\text { Public sector of } \\
\text { Uttarakhand }\end{array}$ & $\begin{array}{l}\text { Technology } \\
\text { Acceptance } \\
\text { Model } \\
\end{array}$ & $\begin{array}{l}\text { Highlighted certain } \\
\text { gaps. }\end{array}$ \\
\hline 14. & $\begin{array}{l}\text { Veit et al. } \\
\text { ( 2011) }\end{array}$ & Germany & $\begin{array}{l}\text { Employees of } 13 \\
\text { German } \\
\text { municipalities }\end{array}$ & $\begin{array}{l}\text { Technology- } \\
\text { Organization- } \\
\text { Environment( } \\
\text { TOE) }\end{array}$ & $\begin{array}{l}\text { Found suitable gaps } \\
\text { in e- procurement } \\
\text { adoption. }\end{array}$ \\
\hline
\end{tabular}

With respect to the pension offices of the government and its automation in Indian perspective, there is a lack of empirically based studies analyzing the adoption and acceptance of egovernance initiative by the government employees. 
International Journal of Managing Public Sector Information and Communication Technologies (IJMPICT)

Vol. 3, No. 1, September 2012

\subsection{Research Model and Hypothesis}

This is the first study conducted on e-governance adoption in the pension office of a provincial government in India, specifically of the State of West Bengal. Pension Management System (PMS) is one of the important e-governance application systems of the Government of West Bengal. In this study, the Unified Theory of Acceptance and Use of Technology (UTUAT) and Trust are integrated to propose a model for employee adoption of e- governance and the conceptual model is shown in Figure 1. UTAUT is considered as it has been established in the study of Gupta et al. (2008) for adoption of e-governance application system by the government employees in India.

The constructs of UTAUT: Performance expectancy, Effort expectancy, Social influence and Facilitating conditions are incorporated into the model. There are four factors: gender, age, experience and voluntariness of use, identified as moderating variables in the original UTAUT. For this study, age, experience and voluntariness of use have been controlled and thus, being removed and not taken into consideration.

The moderating variable experience was controlled. Almost all employees of the organization, nearly $90 \%$, were similar in their experience with the e-governance application system i.e. PMS. Since most employees in the Directorate started using the technology around the same time, any significant variability in experience is usually not found. Therefore, it's being believed that experience would not have a significant moderating effect.

PMS is not voluntary and it is mandatory for the employees to use the application system in order to discharge their official work. So, voluntariness of use has not been taken into consideration. The Theory of Planned Behavior and UTAUT found that age is a significant moderator, whereas other acceptance models such as TAM, TRA and others did not examine the role of age as a moderator. But this finding is limited to western contexts, such as adoption in the USA (Gupta et al. 2008). The basic premise that information systems are adopted and accepted more easily by younger individuals since they have been exposed to computers and the computing environment at an early age, may be true in the developed world but not so in developing countries such as India. In India, a significant portion of the population does not have access to computers. In the government organizations considered for this study it is not generally found that younger employees had a better understanding and exposure to information systems than their older counterparts (Gupta et al. 2008). Therefore, moderating effect of age has not been considered.

Gupta, et al. (2008) found in their empirical study that gender has no effect as moderating factor in the e-governance adoption in the government organization of India. Therefore, gender is also controlled and has not taken into consideration. The addition is the trust constructs which has been incorporated to examine the effect of trust factors with regard to the user acceptance of egovernance. 
International Journal of Managing Public Sector Information and Communication Technologies (IJMPICT) Vol. 3, No. 1, September 2012

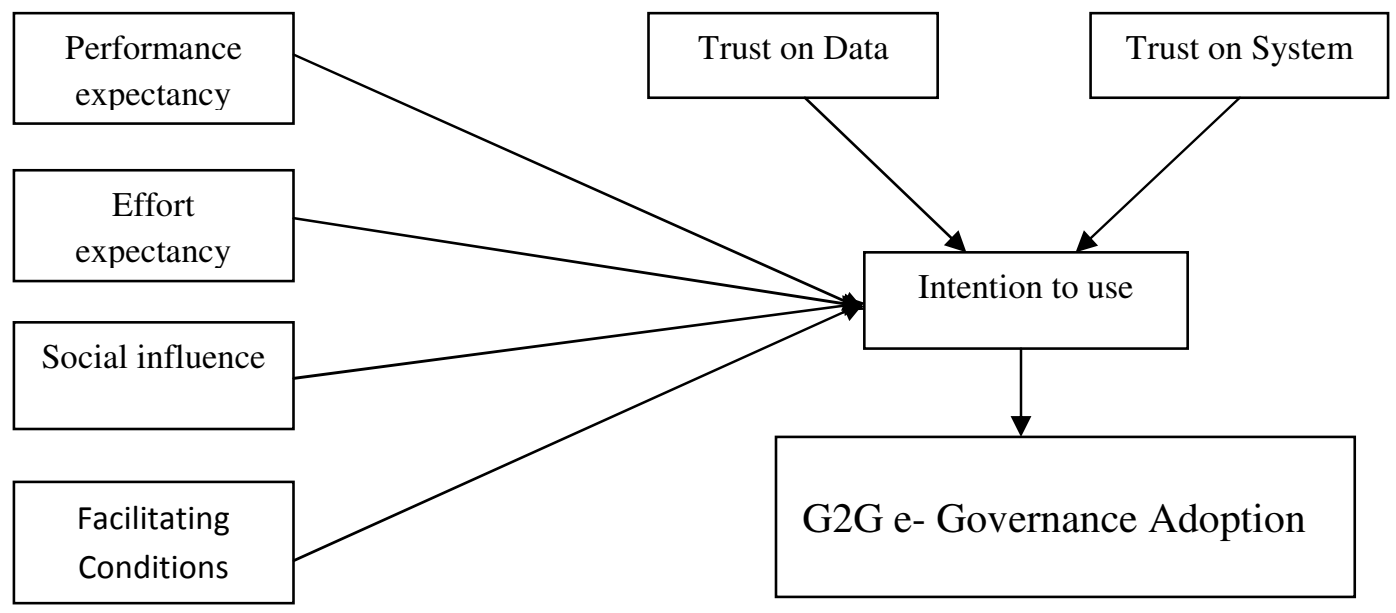

Fig 1: G2G e- Governance Adoption and Acceptance model based on UTAUT and Trust

\section{1 e- Governance and UTAUT}

The UTUAT model has been widely used in the e-governance adoption and acceptance which is shown in Table 1. The employees will find the e-governance system (in this case PMS) useful if it helps them to perform the functions of the Directorate efficiently and effectively. Performance expectancy, effort expectancy and social influence will directly affect the intention to use of the PMS by the officers and staff. Thus, a high level of intention to use is likely to increase employee adoption of PMS. The facilitating conditions such as infrastructure (LAN, Server, SWAN etc) would also positively impact the user acceptance of the e-governance application system, i.e. PMS.

H1. Performance expectancy is positively related to intention to use e-governance application.

H2. Effort expectancy is positively related to intention to use e-governance application.

H3. Social influence is positively related to the intention to use e-governance application.

H4. Facilitating conditions is positively related to the intention to use e-governance application.

\section{2 e- Governance and Trust Literature}

Carter and Belanger (2005), Belanger and Carter (2008), Reddick (2005), West (2004), Riedl (2004), Warkentin et al. (2002) are the main proponents of Trust and empirically established different factors of trust in the citizen adoption of e-government services. There is a wide gap in literature regarding studies that empirically establishes trust as a factor in G2G e-governance adoption and acceptance. As trust is one of the important factors that psychologically shapes the mind of the government employees, therefore it becomes imperative to consider it for this study. The proposed typology of Papadopoulou, et al, (2010) establishing seven variables of trust has been analyzed for this purpose and after due consideration only two variables of trust i.e. Trust on Data and Trust on System out of the seven have been incorporated. Table 3 provides the 
International Journal of Managing Public Sector Information and Communication Technologies (IJMPICT)

Vol. 3, No. 1, September 2012

reasons for both incorporating two variables out of the seven (as given by Papadopoulou et al, 2010) and also rationale behind leaving the other five variables.

Table 3: Variables of Trust

\begin{tabular}{|c|c|c|}
\hline Trust Type & Definition & $\begin{array}{c}\text { Relevancy in G2G } \\
\text { ( in respect of Government in India) }\end{array}$ \\
\hline $\begin{array}{l}\text { Trust in Stored } \\
\text { Data }\end{array}$ & $\begin{array}{l}\text { Trust in the specific e- } \\
\text { government stored data } \\
\text { management (data in } \\
\text { storage/ data access } \\
\text { usage). }\end{array}$ & $\begin{array}{l}\text { This variable is relevant for Government employees. The } \\
\text { financial data of Government is very important and its } \\
\text { importance is being fully understood by all the employees. }\end{array}$ \\
\hline Trust in Service & $\begin{array}{l}\text { Trust in specific e- } \\
\text { government service. }\end{array}$ & $\begin{array}{l}\text { Government employees are service providers to citizens } \\
\text { and not service receivers. So, this variable is not } \\
\text { applicable here. }\end{array}$ \\
\hline $\begin{array}{l}\text { Trust in } \\
\text { Information }\end{array}$ & $\begin{array}{l}\text { Trust in the information } \\
\text { provided by the e- } \\
\text { government. }\end{array}$ & $\begin{array}{l}\text { Government employees provide information and not } \\
\text { receive information. Government employees only receive } \\
\text { instructions and orders decided by the higher authorities. } \\
\text { Thus, this variable also doesn't holds well. }\end{array}$ \\
\hline Trust in System & $\begin{array}{l}\text { Trust in the system/ } \\
\text { infrastructure of the Govt. } \\
\text { organization }\end{array}$ & $\begin{array}{l}\text { This is relevant in the G2G context in Indian government. } \\
\text { Trust on application system and the supporting } \\
\text { infrastructure such as computers, LAN, SWAN etc. has a } \\
\text { positive effect on the employee adoption. }\end{array}$ \\
\hline $\begin{array}{l}\text { Trust in } \\
\text { Transactions }\end{array}$ & $\begin{array}{l}\text { Trust in e-government } \\
\text { transactions }\end{array}$ & $\begin{array}{l}\text { This is more relevant for the citizens. Question of trust on } \\
\text { transactions arises when citizen uses any online web- } \\
\text { based system. }\end{array}$ \\
\hline $\begin{array}{l}\text { Trust in } \\
\text { Government } \\
\text { Organization }\end{array}$ & $\begin{array}{l}\text { Trust in specific } \\
\text { government agency }\end{array}$ & $\begin{array}{l}\text { This is also applicable for G2C. Government and } \\
\text { government agency consists of its employees. Employees } \\
\text { are not required to develop trust on their own organization } \\
\text { or office. }\end{array}$ \\
\hline $\begin{array}{l}\text { Trust in } \\
\text { Government } \\
\text { Organization }\end{array}$ & $\begin{array}{l}\text { Trust in specific } \\
\text { government agency }\end{array}$ & $\begin{array}{l}\text { This is also applicable for G2C. Government and } \\
\text { government agency consists of its employees. Employees } \\
\text { are not required to develop trust on their own organization } \\
\text { or office. }\end{array}$ \\
\hline $\begin{array}{l}\text { Institution } \\
\text { based Trust }\end{array}$ & $\begin{array}{l}\text { Trust in the institutional } \\
\text { system supporting e- } \\
\text { government }\end{array}$ & $\begin{array}{l}\text { This trust is concerned with trust on the legal \& regulatory } \\
\text { framework, standards of the government. This has no } \\
\text { relevance for government employees. This is relevant for } \\
\text { citizens only. }\end{array}$ \\
\hline
\end{tabular}

In the light of the above discussions, it can be considered that Trust on Data and Trust on System would positively influence the employee adoption of the e-governance application.

H5. Trust in stored data is positively related to intention to use e-governance application.

H6. Trust in system is positively related to intention to use e-governance application.

\subsection{Research Methods and Results}

\subsection{Sample and Instrument Development}

The data for the study is collected via a survey questionnaire that was divided into two sections. The first section represents the demographic information about each participant. The subject's perception of each variable in the model is captured in the second section. As the study focuses 
on the e-governance in the Directorate of Pension, Provident Fund and Group Insurance of West Bengal (federal unit of India), so, the target population are the Officers (Director, Joint Directors, Deputy Directors etc.) and the sub-ordinate staffs of the Directorate. The questionnaire is administered to 60 officials and responses are incorporated in the analysis.

As the instrument development is concerned, all the items used in the survey were adapted from previous studies (Venkatesh et al., 2003; Gupta et al, 2008) with some minor changes to the context of the e-governance in West Bengal, India. The measurement of trust on data and trust on system was adapted from the study of Papadpoulou, et al. (2010) and Sang, et al. (2009). Five-point Likert-type scale ranging from 1 (strongly disagree) to 5 (strongly agree) have been incorporated.

In order to enhance the validity of the questionnaire, the readability test was conducted. The Fog Index, Flesch Reading Ease, Flesch- Kincaid Readability Formula and Gunning- Fox Index are the formulas used to determine readability. Flesch- Kincaid Readability Formula test has been applied in this study to determine readability because it is the most widely used. This test rates text on a US school grade level. For example, a score of 8.0 means that an eighth grader can understand the document. The ideal score is considered approximately 7.0 to 8.0. The Table 4 shows the readability score before the test and those having scores more than the grade level of 7.0- 8.0, are brought within the considered level by some modifications. Table 5 represents the final questionnaire.

Table 4: Flesch- Kincaid Readability Grade level score

\begin{tabular}{|c|c|c|}
\hline SL No. & $\begin{array}{c}\text { Readability score of the initial } \\
\text { questionnaire }\end{array}$ & $\begin{array}{c}\text { Readability score after } \\
\text { modifications }\end{array}$ \\
\hline PE 1 & 12 & 8 \\
\hline PE 2 & 8 & 8 \\
\hline PE 3 & 9 & 8 \\
\hline PE 4 & 15 & 8 \\
\hline EE 5 & 10 & 8 \\
\hline EE 6 & 8 & 8 \\
\hline EE 7 & 8 & 8 \\
\hline EE 8 & 8 & 8 \\
\hline SI 9 & 11 & 8 \\
\hline SI 10 & 15 & 8 \\
\hline SI 11 & 13 & 8 \\
\hline SI 12 & 11 & 8 \\
\hline FC 13 & 11 & 8 \\
\hline FC 14 & 14 & 8 \\
\hline FC 15 & 12 & 8 \\
\hline FC 16 & 12 & 8 \\
\hline TD 17 & 11 & 8 \\
\hline TD 18 & 11 & 8 \\
\hline TD 19 & 12 & 8 \\
\hline TS 20 & 13 & \\
\hline & & 8 \\
\hline
\end{tabular}


International Journal of Managing Public Sector Information and Communication Technologies (IJMPICT) Vol. 3, No. 1, September 2012

\begin{tabular}{|c|c|c|}
\hline TS 21 & 9 & 8 \\
\hline TS 22 & 12 & 8 \\
\hline ITU 23 & 11 & 8 \\
\hline ITU 24 & 11 & 8 \\
\hline
\end{tabular}

Table 5: Constructs/ variable and questionnaire items

\begin{tabular}{|c|c|c|c|}
\hline $\begin{array}{l}\text { Construct/ } \\
\text { variable }\end{array}$ & $\begin{array}{c}\text { Scaled } \\
\text { variable }\end{array}$ & & Questionnaire items \\
\hline \multirow[t]{4}{*}{$\begin{array}{l}\text { Performance } \\
\text { expectancy }\end{array}$} & \multirow[t]{4}{*}{$\mathrm{PE}$} & PE 1 & $\begin{array}{l}\text { I am able to do my official work very easily with } \\
\text { PMS. }\end{array}$ \\
\hline & & PE 2 & $\begin{array}{l}\text { PMS enables me to accomplish my work more } \\
\text { quickly. }\end{array}$ \\
\hline & & PE 3 & $\begin{array}{l}\text { PMS increases my productivity in the job. It helps } \\
\text { me to discharge more work in lesser time and } \\
\text { without any error or mistake. }\end{array}$ \\
\hline & & PE 4 & $\begin{array}{l}\text { I could get promotion in my job if I can efficiently } \\
\text { use the PMS. }\end{array}$ \\
\hline \multirow[t]{4}{*}{$\begin{array}{l}\text { Effort } \\
\text { expectancy }\end{array}$} & \multirow[t]{4}{*}{$\mathrm{EE}$} & EE 5 & $\begin{array}{l}\text { By using PMS, all the work of the office is done } \\
\text { quickly. It also helps me to keep a look on the other } \\
\text { functions of the office done by the officials. }\end{array}$ \\
\hline & & EE 6 & $\begin{array}{l}\text { PMS takes less time to do tasks than the manual } \\
\text { system of entries and recording. Earlier the manual } \\
\text { system would take lot of time which has been } \\
\text { reduced in PMS. }\end{array}$ \\
\hline & & EE 7 & $\begin{array}{l}\text { I find the PMS easy to use. I don't see any } \\
\text { complicated process or difficulty in using the system. }\end{array}$ \\
\hline & & EE 8 & $\begin{array}{l}\text { It is easy to learn how to use the PMS and after } \\
\text { proper learning it makes the work easier. }\end{array}$ \\
\hline \multirow[t]{4}{*}{$\begin{array}{l}\text { Social } \\
\text { influence }\end{array}$} & \multirow[t]{4}{*}{ SI } & SI 9 & $\begin{array}{l}\text { PMS increases my respect among the service } \\
\text { colleagues. }\end{array}$ \\
\hline & & SI 10 & $\begin{array}{l}\text { I feel very proud to work with PMS as it is } \\
\text { considered the most efficient intra-governmental } \\
\text { system. }\end{array}$ \\
\hline & & SI 11 & $\begin{array}{l}\text { We get all the required help from the Finance } \\
\text { Department for the proper working and maintenance } \\
\text { of the PMS. }\end{array}$ \\
\hline & & SI 12 & $\begin{array}{l}\text { The employees provide their support in proper } \\
\text { running of the PMS. They put equal efforts in } \\
\text { discharging the office functions as efficiently and } \\
\text { quickly as possible. }\end{array}$ \\
\hline \multirow[t]{3}{*}{$\begin{array}{l}\text { Facilitating } \\
\text { conditions }\end{array}$} & \multirow[t]{3}{*}{ FS } & FS 13 & $\begin{array}{l}\text { Proper training is provided to use the system. The } \\
\text { process of using the PMS is clearly demonstrated in } \\
\text { the training sessions. }\end{array}$ \\
\hline & & FS 14 & $\begin{array}{l}\text { When any problem arises in the PMS software the } \\
\text { help of the support staff are quickly available. }\end{array}$ \\
\hline & & FS 15 & $\begin{array}{l}\text { The physical infrastructure (LAN, Server, Computers } \\
\text { etc.) works properly. There is good external back-up } \\
\text { for power which is the main requirement for running }\end{array}$ \\
\hline
\end{tabular}


International Journal of Managing Public Sector Information and Communication Technologies (IJMPICT) Vol. 3, No. 1, September 2012

\begin{tabular}{|c|c|c|c|}
\hline & & & the PMS. \\
\hline & & FS 16 & $\begin{array}{l}\text { The support of the hardware engineers is also quickly } \\
\text { available in case of crisis situations. }\end{array}$ \\
\hline $\begin{array}{l}\text { Trust on } \\
\text { data }\end{array}$ & TD & TD 17 & $\begin{array}{l}\text { There is good data back-up system in the PMS. As } \\
\text { the Directorate deals with high volume of financial } \\
\text { data, the back-up system in the PMS is quite } \\
\text { satisfactory. There is also provision of external back- } \\
\text { up system besides the internal system. }\end{array}$ \\
\hline & & TD 18 & $\begin{array}{l}\text { I easily retrieve (able to get) the historical data } \\
\text { (previous data) when required. I don't need to waste } \\
\text { much time getting the previous data as the system is } \\
\text { having smart feature of quick retrieval of data. }\end{array}$ \\
\hline & & TD 19 & $\begin{array}{l}\text { As the Directorate deal with high value financial data } \\
\text { of the government, so there is need of proper } \\
\text { protection of the data. Data remains secured and } \\
\text { protected in the PMS and there is no fear of losing } \\
\text { the data or unofficial use of the data. }\end{array}$ \\
\hline $\begin{array}{l}\text { Trust on } \\
\text { system }\end{array}$ & $\mathrm{TS}$ & TS 20 & $\begin{array}{l}\text { I feel the infrastructure of the Directorate (LAN, } \\
\text { SWAN, Connectivity, Servers etc.) are reliable } \\
\text { (trustable) and works properly. }\end{array}$ \\
\hline & & TS 21 & $\begin{array}{l}\text { PMS is fault free as much as my work is concerned. } \\
\text { It means that the application system is perfect and } \\
\text { has no short-comings. It covers all the functions } \\
\text { performed in the Directorate and the application } \\
\text { system does completely error free task. }\end{array}$ \\
\hline & & TS 22 & $\begin{array}{l}\text { The system is fully protected against intrusion } \\
\text { threats. There is no fear of hacking or other external } \\
\text { threats. As many government websites and other } \\
\text { applications are often hacked or manipulated by } \\
\text { external powers, but in case of PMS, I have firm } \\
\text { believe that such threats and fear do not exists. }\end{array}$ \\
\hline $\begin{array}{l}\text { Intention to } \\
\text { Use }\end{array}$ & ITU & ITU 23 & $\begin{array}{l}\text { I would surely use PMS whenever I will be given the } \\
\text { access of the system. }\end{array}$ \\
\hline & & ITU 24 & $\begin{array}{l}\text { I have access to PMS and I would surely do my } \\
\text { official work with its help. }\end{array}$ \\
\hline
\end{tabular}

The reliability of each item in the questionnaire was examined using Cronbach's alpha (Cronbach, 1970). All the items are above the acceptance level of 0.7 (Hair et al., 2006) and shown in Table 7. Factor analysis of the items of the questionnaire is conducted to check for construct validity. Its being found that all the items of the questionnaire are proper measures of the questionnaire and the factor loadings are proper, shown in Table 8.

\subsection{Demographic Analysis}

The profile of the demography captured shown in Table 6 shows that there are predominantly male ( 87 percent as compared to females 13 percent). The employees within the age group of 46 to 55 years are dominant (60 percent) and all with more than 10 years of service experience (100 
International Journal of Managing Public Sector Information and Communication Technologies (IJMPICT) Vol. 3, No. 1, September 2012

percent). As the education and level of computer knowledge is concerned, bachelor's degree are dominant (67 percent) and 87 percent are having basic knowledge of computers. The basic knowledge of computers, here, signifies 6 months diploma course.

Table 6: Demographic profile of the respondents

\begin{tabular}{|c|c|c|c|}
\hline Particulars & Variables & Frequency & $\begin{array}{c}\text { Percentage } \\
(\%)\end{array}$ \\
\hline \multirow[t]{2}{*}{ Gender } & Male & 52 & 87 \\
\hline & Female & 08 & 13 \\
\hline \multirow[t]{4}{*}{ Age } & 18 to 25 & 00 & 00 \\
\hline & 26 to 35 & 07 & 12 \\
\hline & 36 to 45 & 17 & 28 \\
\hline & 46 to 55 & 36 & 60 \\
\hline \multirow[t]{3}{*}{ Education } & High School & 12 & 20 \\
\hline & Graduate & 40 & 67 \\
\hline & Post Graduate & 08 & 13 \\
\hline \multirow{4}{*}{$\begin{array}{l}\text { Years of } \\
\text { Service }\end{array}$} & Less than 1 & 00 & 00 \\
\hline & 1 to 5 & 00 & 00 \\
\hline & 6 to 10 & 00 & 00 \\
\hline & More than 10 & 60 & 100 \\
\hline \multirow{4}{*}{$\begin{array}{l}\text { Computer } \\
\text { Knowledge }\end{array}$} & Basic & 52 & 87 \\
\hline & Level O & 08 & 13 \\
\hline & Level B & 00 & 00 \\
\hline & Level A & 00 & 00 \\
\hline \multirow{2}{*}{$\begin{array}{l}\text { Respondents } \\
\text { (total 60) }\end{array}$} & Officers & 14 & 23 \\
\hline & Subordinate Staffs (non-officers) & 46 & 77 \\
\hline
\end{tabular}

Table 7: Reliability analysis

\begin{tabular}{|c|c|c|}
\hline \multirow{2}{*}{ Construct } & No. of items & Cronbach's Alpha \\
\hline Performance expectancy & PE 1 & .880 \\
\cline { 2 - 3 } & PE 2 & .879 \\
\cline { 2 - 3 } & PE 3 & .884 \\
\cline { 2 - 3 } & PE 4 & .881 \\
\hline \multirow{2}{*}{ Effort expectancy } & EE 1 & .878 \\
\cline { 2 - 3 } & & .885 \\
\cline { 2 - 3 } & EE 2 & .882 \\
\cline { 2 - 3 } & EE 3 & .880 \\
\hline Social influence & EE 4 & .877 \\
\hline & & .879 \\
\hline
\end{tabular}


International Journal of Managing Public Sector Information and Communication Technologies (IJMPICT) Vol. 3, No. 1, September 2012

\begin{tabular}{|c|c|c|}
\hline \multirow{4}{*}{ Facilitating conditions } & SI 4 & .881 \\
\cline { 2 - 3 } & & .883 \\
\cline { 2 - 3 } & FC 1 & .888 \\
\cline { 2 - 3 } & FC 2 & .888 \\
\cline { 2 - 3 } & FC 3 & .887 \\
\hline \multirow{2}{*}{ Trust on data } & FC 4 & .881 \\
\cline { 2 - 3 } & & .881 \\
\cline { 2 - 3 } & TD 1 & .883 \\
\hline Trust on system & TD 2 & .882 \\
\cline { 2 - 3 } & TD 3 & .888 \\
\cline { 2 - 3 } & & .890 \\
\cline { 2 - 3 } & TS 1 & .876 \\
\hline Intention to use & TS 2 & .880 \\
\hline
\end{tabular}

Table 8: Results of Factor Analysis

\begin{tabular}{|c|c|c|}
\hline Construct & No. of items & Factor Loading \\
\hline \multirow[t]{4}{*}{ Performance expectancy } & PE 1 & .927 \\
\hline & PE 2 & .750 \\
\hline & PE 3 & .803 \\
\hline & PE 4 & .753 \\
\hline \multirow[t]{4}{*}{ Effort expectancy } & EE 1 & .884 \\
\hline & EE 2 & .809 \\
\hline & EE 3 & .633 \\
\hline & EE 4 & .738 \\
\hline \multirow[t]{4}{*}{ Social influence } & SI 1 & .748 \\
\hline & SI 2 & .845 \\
\hline & SI 3 & .811 \\
\hline & SI 4 & .730 \\
\hline \multirow[t]{4}{*}{ Facilitating conditions } & FC 1 & .792 \\
\hline & FC 2 & .784 \\
\hline & FC 3 & .692 \\
\hline & FC 4 & .759 \\
\hline \multirow[t]{3}{*}{ Trust on data } & TD 1 & .723 \\
\hline & TD 2 & .888 \\
\hline & TD 3 & .717 \\
\hline \multirow[t]{3}{*}{ Trust on system } & TS 1 & .880 \\
\hline & TS 2 & .658 \\
\hline & TS 3 & .796 \\
\hline
\end{tabular}


International Journal of Managing Public Sector Information and Communication Technologies (IJMPICT) Vol. 3, No. 1, September 2012

\begin{tabular}{|c|c|c|}
\hline & & \\
\hline \multirow{2}{*}{ Intention to use } & ITU 1 & .850 \\
\cline { 2 - 3 } & ITU 2 & .786 \\
\hline
\end{tabular}

\subsection{Regression Results}

The original UTAUT model used partial least squares (PLS) as the data analysis technique. Gupta et al. (2008) used the regression analysis and ran separate regressions to test the independent effect of performance expectancy, effort expectancy, social influence and facilitating conditions. As the study of Gupta et al. (2008) is based on the employee adoption of e-governance in government organization in India, therefore, in this paper, separate regressions test are ran to analyze all the variables including trust on data and trust on system. Table 9 represents the regression variables and Table 10 shows the regression results.

Table 9: Regression variables

\begin{tabular}{|c|c|c|c|c|}
\hline $\begin{array}{c}\text { Dependent } \\
\text { Variable }\end{array}$ & $\begin{array}{c}\text { Independent } \\
\text { Variable }\end{array}$ & No. of Items & Mean & SD \\
\hline \multirow{4}{*}{ ITU } & PP & 4 & 3.98 & .331 \\
\cline { 2 - 5 } & EE & 4 & 4.54 & .335 \\
\cline { 2 - 5 } & SI & 4 & 4.43 & .351 \\
\cline { 2 - 5 } & FC & 4 & 3.94 & .174 \\
\cline { 2 - 5 } & TD & 3 & 4.22 & .335 \\
\cline { 2 - 5 } & TS & 3 & 3.34 & .157 \\
\hline
\end{tabular}

Table 10: Regression results

\begin{tabular}{|c|c|c|c|c|c|c|}
\hline Hypotheses & $\mathbf{R}^{\mathbf{2}}$ & F value & Coefficient & t- value & Significant & Supported \\
\hline H1 & .238 & 18.109 & .488 & 2.662 & .010 & Yes \\
\hline H2 & .085 & 5.413 & .292 & 2.327 & .024 & Yes \\
\hline H3 & .381 & 35.730 & .617 & 5.977 & .000 & Yes \\
\hline H4 & .174 & 12.189 & .417 & 3.491 & .001 & Yes \\
\hline H5 & .151 & 10.353 & .389 & 3.218 & .002 & Yes \\
\hline H6 & .075 & 4.731 & .275 & 2.175 & .034 & Yes \\
\hline
\end{tabular}

\subsection{Discussion of Results}

$\mathrm{H} 1$ is supported and it shows that performance expectancy is positively related to the intention to use of the e-governance application. Performance expectancy is the degree to which an individual believes that using a system will help him/ her to attain gains in job performance or to get good performance appraisal. The results show that an increase in performance expectancy influences behavior intention to use the PMS, and it supports the UTAUT model (Venkatesh et al. 2003). Performance expectancy is theoretically derived from constructs such as user's intention to use a technology, thus it can be substantiated that the present findings support the existing literature. PMS is successful in replacing the cumbersome manual system. The employees believe that it helps them to accomplish their tasks more easily and in a faster way which ultimately results in their official performances. It also supports critical aspects of their official work and enhances their efficiency on the job.

Effort expectancy is the degree associated with the ease associated with the use of the system (Venkatesh et al. 2003). In this study, it is found that effort expectancy influences the employees 
intention to use the e-governance application system and the second hypotheses $\mathrm{H} 2$ is supported. The responses of the respondents shows that overall, they find the application system easy to use. This supports the existing literature on the topic that use of a system is dependent on how easy it is to use it.

Social influence is the degree to which an individual perceives that important others believe he/she should use the new system. Social influence in UTAUT is represented as subjective norm in other models such as TRA, TPB and image in IDT (Venkatesh et al. 2003). Social influence has been found positively influencing the employee's intention to use and thus, H3 is supported. Thus, the findings support the existing literature that social influence has significant effect on behavioral intention to use a system. The employees believe that PMS increases their respect among the other service colleagues working in different departments and organizations of the Government of West Bengal.

$\mathrm{H} 4$ is also supported. Facilitating conditions also positively influences and having significant impact on the intention to use the PMS. Facilitating conditions refer to the degree to which an individual believes that an organizational and technical infrastructure is proper and support the system. It is derived from perceived behavioral control from TAM and TPB, and compatibility from IDT and is considered to be an important determinant of use of a system. The present findings support the UTAUT results that facilitating conditions to be an important determinant of system use and adoption. The employees find the LAN, WBSWAN, Servers, computers, power back-up all are properly working and if any technical problem arises than the support of the technical staffs are quickly available. Minimum training of maintenance of the hardware is given to the officials also.

H5 is also supported and trust on data has significant impact on the user intention. The employees find that the system has good data back-up facility, they can easily retrieve the historical data and more importantly they have full confidence that the data, which are of high financial value and importance, are fully secured and are not misused or used unofficially.

Trust on system has significant influence on the behavior of the user towards the use of PMS which is established and H6 is also supported. The officers believe that there is no fear of hacking or external threats like other government websites and applications. They also satisfied with the infrastructure of the treasury to support the application system.

In summary, our findings shows that performance expectancy, effort expectancy, social influence, facilitating conditions, trust on data and trust on system has a significant positive impact on the intention to use the PMS of the Directorate of Pension, Provident Fund and Group Insurance (DPPG), Government of West Bengal. The officials believe that PMS makes their work easier, enhances their performances on the job, time saving and easy to use, highly secured and protected. They also have trust on the application system.

\subsection{Conclusions}

The purpose of the study is to analyze the adoption of e-governance by the government employees who are acting as facilitator of the services to the people and main players in the inter-governmental operations. Our results validate the conceptual model (Figure 1) and show the successful e-governance adoption and acceptance in the Directorate of Pension, Provident Fund \& Group Insurance (DPPG), Government of West Bengal, India. 
This study has important practical implications for the government decision makers. The egovernance initiatives in this Directorate started in 1990 and till date no analysis in the form of any impact assessment, information technology audit or any other has been conducted either at the official level or by academic research.

This study shows that the application system of the Directorate is free from the deficiencies of faulty design, inadequate security controls, improper connectivity \& infrastructure, nonintegration of modules etc. This application system of West Bengal can be adopted and replicated by the Directorates of other States of India (other federal units).

The study has its limitations. The efficacy and success of the e-governance initiatives in the pension office of Government of West Bengal (i.e. Directorate of Pension, Provident Fund \& Group Insurance) can only be established if it is being compared with the similar e-governance initiatives in the pension offices of other States of India. . Despite this limitation, the study makes a significant contribution. The e-governance in the pension office started in the State of West Bengal in 1990 and it is the most robust application system handling the pension cases of more than 65000 peoples in a year. There is no previous study which made an attempt to analyze the acceptance of the e-governance initiative by the employees of this Directorate.

There is ample scope of future research in this area. It order to apprehend the success of egovernance initiatives in the Directorate of Pension, Provident Fund \& Group Insurance (DPPG), Government of West Bengal, the empirical study of the e-governance initiatives for the pensioners and other beneficiary citizens, taken by the Directorate on and after 2008 need to be analyzed. Such as the Directorate launched 'Pension File Status Query System' and hosted it under the portal of the Finance Department. Similar empirical studies may be conducted in other States of India which would facilitate the State governments to know the acceptance of the system by its officers and subordinate staffs. Higher degree of acceptance would increase the efficiency of the system and would show the success of the e-governance initiatives of the government. There is also scope of comparative analysis of the systems of different States of India.

\section{References}

[1] A. Keramati and A. Chelbi, "The Adoption of E-Government Services by Employees in Iran, Case Study: Rasht Municipality", Department of Business Administration and Social Sciences, Lulea University of Technology, 2011.

[2] A.F Realini, "G2G E- Government: The Big Challenge for Europe", Master Thesis, Department of Informatics, University of Zurich, 2004.

[3] Annual Report. Directorate of Commercial Tax, Government of West Bengal, India, 2010-11.

[4] B. Gupta., S. Dasgupta and A. Gupta, "Adoption of ICT in a government organization in a developing country: An empirical study”, Journal of Strategic Information System, vol. 17, pp. 140-154, 2008.

[5] C. G. Reddick and H. A. Frank, "The perceived impacts of e-government on US cities: A survey of Florida and Texas City Managers", Government Information Quarterly, vol. 24, pp. 576-594, 2007.

[6] C. Reddick, "Citizen interaction with e-government: from the streets to servers?", Government Information Quarterly, vol. 22, pp. 38-57, 2005. 
International Journal of Managing Public Sector Information and Communication Technologies (IJMPICT) Vol. 3, No. 1, September 2012

[7] D. J. Veit, N. P. Parasie, \& Jan C. Huntgeburth, "E- Procurement Adoption at the Municipal level: Influence of Organizational, Technological and Environmental Factors", in Proceedings of $44^{\text {th }}$ Hawaii International Conference on System Sciences, USA, 2011.

[8] Dawood. Hussain Sallem, "Identifying Factors That Influence the Utilization of Agribazar Portal", Universiti Utara, Malaysia, 2009.

[9] D. Gilbert and P. Balestrini, "Barriers and Benefits in the Adoption of e- Government", The International Journal of Public Sector Management, vol. 17, no. 4, pp. 286-301, 2004.

[10] D. West, "E-government and the Transformation of Service Delivery and Citizen Attitudes", Public Administration Review, vol. 64, pp. 15-27, 2004.

[11] Eija. Korpelainen, "Theories of ICT System Implementation and Adoption - A Critical Review, Working Paper, Department of Industrial Engineering and Management, School of Science, Aalto University, Helsinki, 2011.

[12] E. M. Rogers, "Diffusion of Innovations", 3th edition; 4th edition, New York: Free Press, 1983, 1995.

[13] F. Belanger \& L. Carter, "Trust, and risk in e-government adoption", The Journal of Strategic Information Systems, vol. 17, no. 2, pp. 165- 176, 2008.

[14] F. Davis, "Perceived Usefulness, perceived ease of use, and user acceptance of information technology", MIS Quarterly, vol. 13, no. 3, pp. 319- 340, 1989.

[15] Frank K.Y Chan, Y.L James Thong, Vishwanath. Venkatesh, Sue. A Brown, Paul J.H Hu and Kar. Yan Tam, "Modelling Citizen Satisfaction with Mandatory Adoption of E- Government Technology", Journal of the Association for Information Systems, vol. 1, no. 10, pp. 519-549, 2010.

[16] George. Foteinou, "E- Government Adoption in the EU: Theoretical and Methodological Challenges in the Study of the Digital Divide".

[17] G. Bouckaert and S.Van de Walle, "Government Performance and Trust in Government", Paper for the Permanent Study Group of Productivity and Quality in the Public Sector at the EGPA Annual Conference, Vaasa, Finland, September, 2001.

[18] G.P Sahu and M.P Gupta, "User's Acceptance of E- Government: A Study of Indian Central Excise", International Journal of Electronic Government Research, vol. 3, no. 8, pp. 1-21, 2007.

[19] Homoud. Shafi. Al-Shafi, "Factors Affecting E-Government Implementation and Adoption in the State of Qatar. School of Information Systems", Computing and Mathematics, Department of Information Systems, Brunel University, London, UK, 2009

[20] I. Ajzen, "From intentions to actions: A theory of planned behavior", in J. Khul \& J. Beckman (Eds.), Action control: From cognition to behavior, pp. 11-39, Heidelberg, Springer, 1985

[21] I. Ajzen, "The theory of Planned Behavior. Organizational Behavior and Human Decision Process", vol. 50, no. 2, pp. 179-211, 1991.

[22] I. Benbasat and H. Barki, "Quo Vadis, TAM?", Journal of the Association for Information Systems, vol. 8, no. 4, pp. 211-218, 2007. 
International Journal of Managing Public Sector Information and Communication Technologies (IJMPICT) Vol. 3, No. 1, September 2012

[23] Ibrahim. Elbeltagi, Neil. Mcbride and Glenn. Hardekar, "Evaluating the Factors Affecting DSS Usage by Senior Managers in Local Authorities in Egypt", Journal of Global Information Management, vol. 13, no. 2, pp. 42-65, 2005.

[24] Inder Singh and Devendra Kumar Punia, "Employees Adoption of E- Procurement System: An Empirical Study”, Journal of Managing Information Technology, vol. 3, no. 4, 2011.

[25] Indeeran Vencatachellum and Sharmila Pudaruth, "Investigating E-Government Services Uptake in Mauritius: A User's Perspective", International Research Symposium in Service Management, Mauritius. August, 2010.

[26] J.F Hair, W.C Black Jr., B.J Babin, R.E Anderson and R.L Tatham, Multivariate Data Analysis, Pearson Prentice Hall, Upper Saddle River, NJ, 2006.

[27] L. Abdulwahab and Z.M Dahalin, "A Conceptual Model of Unified Theory of Acceptance and Use of Technology (UTAUT) Modification with Management Effectiveness and Program Effectiveness in Context of Telecentre," African Scientist, vol. 11, no. 4, 2010.

[28] L. Carter and F. Belanger, "The utilization of e-government services: citizen trust, innovation and acceptance factors", Information Systems Journal, vol. 15, no. 1, pp. 5-25, 2005.

[29] Luarn. Pin and Pin. Huang, "Factors Influencing Government Employee Performance via Information Systems Use: an Empirical Study", Electronic Journal of e-Government, vol. 7, no. 3, pp. 227-240, 2009.

[30] Moaman. Al- Busaidy and Vishanth. Weerakkody, "E- government diffusion in Oman: a public sector employee's perspective", Transforming Government: People, Process and Policy, vol. 3, no. 4, pp. 375-393, 2009.

[31] M.E. Alzahrani and R.D. Goodwin, "Towards a UTAUT based Model for the Study of EGovernment Citizen Acceptance in Saudi Arabia", World Academy of Science, Engineering and Technology, 2012.

[32] M. Fishbein and I. Ajzen, Belief, attitudes, intention and behavior. Reading, MA: Addison- Wesley, 1975 .

[33] M. Warkentin, D. Gefen, P.A Pavloua and G.M Rose, "Encouraging citizen adoption of egovernment by building trust", Electronic Markets, vol. 12, no. 3, pp. 157- 162, 2002.

[34] Nipendra P. Rana, Michael D. Williams, Yogesh K. Dwivedi and Janet Williams, "Reflecting on EGovernment Research: Toward Taxonomy of Theories and Theoretical Constructs", tGov Workshop'11 (tGOV 211), Brunel University, London, March, 2011.

[35] Panagiota. Papadopoulou, Maria Nikolaidou and Drakoulis Martakos, "What is Trust in EGovernment? A Proposed Typology", in Proceedings of the 43th Hawaii International Conference on System Sciences, 2010.

[36] Pietro. Previtali and Francesco. Bof, "E- government adoption in small Italian municipalities", International Journal of Public Sector Management, vol. 22, no. 4, pp. 338-348, 2009.

[37] P. Pavlou, "Consumer Acceptance of Electronic Commerce: Integrating Trust and Risk with the Technology Acceptance Model”, International Journal of Electronic Commerce, vol. 7, no. 3, pp. 69-103, 2003. 
International Journal of Managing Public Sector Information and Communication Technologies (IJMPICT) Vol. 3, No. 1, September 2012

[38] R. B. Cooper and R. W. Zmud, "Information Technology Implementation Research: A Technological Diffusion Approach”, Management Science, vol. 36, no. 2, pp. 123-139, 1990.

[39] R. Riedl, "Rethinking trust and confidence in European e-government: Linking the public sector with post-modern society", In Building the E-Service Society: E-Commerce, E-Business, and E-Government, ed W. Lamersdorf, V. Tschammer and S. Amarger. Norvell, MA: Kluwer, pp. 89-108, 2004.

[40] Said.S Al- Gahtami, Geoffery. S Hubona and Jijie. Wang, "Information Technology (IT) in Saudi Arabia: Culture and the acceptance and use of IT", Information and Management, vol. 44, no. 8, pp. 681691, 2007.

[41] Shafi. Al- Shafi and Vishanth. Weerakkody, "Understanding Citizen's Behavioral Intention in the Adoption of E-Government Services in the State of Qatar", in $17^{\text {th }}$ European Conference on Information Systems, Verona, Italy, 2009.

[42] Siddartha. S. Padhi.., and Pratap K.J Mohapatra, "Adoption of e- procurement in the government departments", International Journal of Electronic Government, vol. 7, no. 1, pp. 41-59, 2010.

[43] Sinawong. Sang, "E-government adoption in Cambodia: a partial least squares approach", Transforming Government: People, Process and Policy, vol. 4, no. 2, pp. 138-157, 2010.

[44] Sinawong Sang., Jeong- Dong Lee and Jongsu Lee, "E- government adoption in ASEAN: the case of Cambodia", Internet Research, vol. 19, no. 5, pp. 517-534, 2009.

[45] Shin-Yuan Hung, King- Zoo Tang, Chia- Ming Chang and Ching- De Ke, "User acceptance of intergovernmental services: An example of electronic document management system", Government Information Quarterly, vol. 26, pp. 387-397, 2009.

[46] Sofia. Elena Colesca, "Increasing E- Trust: A Solution to Minimize Risk in E- Government Adoption”, Journal of Applied Quantitative Methods, vol. 4, no.1, 2009.

[47] Sofia. Elena Colesca and Dobrica. Liliana, "E- government Adoption in Romania", International Journal of Human and Social Sciences, vol. 4, no. 14, 2009.

[48] Solomon Neqash Lemma Lessa and Donald L. Amoroso, "Acceptance of WoredaNet E-Government Services in Ethopia: Applying the UTAUT Model", Proceedings of the Seventheenth American Conference on Information Systems, Detroit, Michigan, August, 2011.

[49] Suha. AlAwadhi and Anne. Morris, "The Use of the UTAUT Model in the Adoption of EGovernment Services in Kuwait", in HICSS' 08 Proceedings of the Proceedings of the $41^{\text {st }}$ Annual Hawaii International Conference on System Sciences, pp. 452, 2008.

[50] S. Zouridis and M. Thaens, "Reflections on the anatomy of E-Government", In V. Bekkers and V. Homburg (Eds.). The information ecology of e-government. IOS Press, Amsterdam, 2005.

[51] Thamer. Alhussain and Steve. Drew, “Employees' Perceptions of Biometrics Technology Adoption in E- Government: An Exploratory Study in the Kingdom of Saudi Arabia", International Journal of EAdoption, vol. 2, no. 1, 2010.

[52] Vichita Vathanophas, Nattapon Krittayaphongphun and Chaalai Klomsiri, "Technology Acceptance of Internet Toward E- Government Initiative in Naval Finance Department of Royal Thai Navy", in eGovernment Workshop’ 06 (eGOV 06), Brunel University, West London, September, 2006. 
International Journal of Managing Public Sector Information and Communication Technologies (IJMPICT) Vol. 3, No. 1, September 2012

[53] Vitality. Baev, "E- governance in Developing Countries", IICD Research Brief, no. 1, March, 2001.

[54] V. Venkatesh, M.G Morris, G.B Davis and F.D Davis, "User acceptance of information technology: Toward a unified view”, MIS Quarterly, vol. 27, no.3, pp. 425-478, 2003.

[55] W. H DeLone and E. R. McLean, "Information Systems Success: The Quest for the Dependent Variable", Information Systems Research, vol. 3, no. 1, pp. 60-95, 1992.

[56] Z. Fang, "E- government in Digital Era: Concept, Practice and Development. International Journal of the Computer", The Internet and Management, vol. 10, no. 2, pp. 1-22, 2002.

\section{Author:}

Mithun Barua is officer of the Government of West Bengal, India working in the domain of e-governance, general administration and financial administration. Headed a project on e-governance for 3 years. Also PhD scholar at L.M Thapar School of Management, Thapar University, Patiala, India from 2010. Done research work on employee adoption of e-governance in the different organizations of Government of West Bengal, e-participation in the Urban Local Bodies (ULBs), Right to Public Serv ices Act and on the network connectivity for the e-governance projects. Has been selected for the Estonian Government Short-term Research Grant on the domain of 'e- services and mobile governance' and Doctoral Support Program (DSP) at the Department of Public Policy, Central European University, Budapest, Hungary.

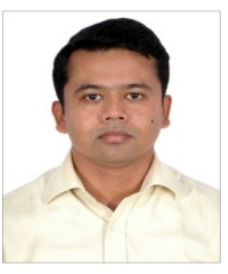

